\title{
VEGF-C level as a predictor of pelvic lymph node metastases of cervical cancer at early stage
}

Andrijono, ${ }^{1}$ Heru Priyanto ${ }^{2}$

1 Department of Obstetrics and Gynecology, Faculty of Medicine University of Indonesia Cipto Mangunkusumo Hospital, Jakarta, Indonesia

2 Department of Obstetrics and Gynecology, Faculty of Medicine University of 11 Maret dr Muwardi Hospital, Surakarta, Indonesia

\begin{abstract}
Abstrak
Tujuan VEGF bekerja merangsang angiogenesis dan limfogenesis yang merupakan salah satu factor pada proses metastasis. Apakah kadar VEGF dapat digunakan memprediksi metastasis kanker serviks stadium IB-IIA.

Metode Penelitian kasus (kanker serviks metastasis ke kelenjar getah bening pelvik) kontrol (kanker serviks tanpa metastasis). Variabel independent adalah ukuran lesi primer, jenis histologi, derajat differensiasi sel, lymph vascular space involvement, dan kadar VEGF. Variabel dependent adalah kejadian metastasis ke kelenjar getah bening pelvik.

Hasil Berdasarkan cut-off point kadar VEGF-C serum yaitu 10.066,90 pg/ml, 11/47 pasien atau 23,41\% mempunyai kadar diatas nilai tersebut dan 10/11 dari kelompok pasien tersebut atau 90,91\% didapatkan metastasis pada kelenjar getah bening pelvik. Sensitifitas pemeriksaan kadar VEGF-C terhadap risiko terjadinya metastasis KGB pada penelitian ini adalah $71,43 \%$ dengan spesifitas $96,97 \%$, positive predictive value (PPV) 90,91\% dan negative predictive value $88,89 \%$.
\end{abstract}

Kesimpulan Kadar VEGF-C dalam serum dapat digunakan untuk memprediksi metastasis kanker serviks stadium IB-IIA dengan sensitivitas 71,43\% dan spesifitas 96,97\%. (Med J Indones 2009; 18: 257-61)

\begin{abstract}
Aim Vascular endothelial growth factor (VEGF) works to stimulate angiogenesis and lymphogenesis which is one of the factors in the metastasis process. This study aimed to identify whether VEGF level could be used to predict metastasis into pelvic lymph node of stage IB-IIA cervical cancer.

Methods The study was case control study, a case (cervical cancer metastasis into pelvic lymph node), a control (cervical cancer without metastasis). Independent variables included primary lesion size, histological type, grade of cell differentiation, lymph vascular space involvement, and VEGF level. Dependent variable was metastasis into pelvic lymph node.

Results Based on cut-off point, VEGF-C serum level, i.e., 10,066.90 pg/ml, 11/47 patients or 23.41\%, had the level above that value, and $10 / 11$ of the group of patient or $90.91 \%$ were found to develop metastasis into pelvic lymph node. Sensitivity of the examination of VEGF-C level in relation to the risk for the incidence of lymph node in this study was $71.43 \%$, with a specificity of $96.97 \%$, positive predictive value (PPV) of $90.91 \%$, and negative predictive value (NPV) of $88.89 \%$.

Conclusion VEGF-C level in the serum could be used to predict lymph node metastasis of stage IB-IIA cervical cancer, with a sensitivity of $71.43 \%$ and specificity of 96.97\%. (Med J Indones 2009; 18: 257-61)
\end{abstract}

Key words: cervical cancer, metastasis, VEGF

Several prognosis factors of metastasis into the pelvic lymph node of cervical carcinoma include, among others, primary lesion size, histological type, and degrees of cell differentiation. Metastasis into lymph node reduces 5 -year survival by $35 \%$, and the administration of adjuvant therapy of radiation would increase 5-year survival by $5 \% .1$ The results of surgical therapy are similar to those of radiation therapy, such that patients with early stage cervical cancer that has metastasized into pelvic lymph node should be administered radiation therapy. Metastatic process occurs through stages of metastasis, one of which is endothelial proliferation in angiogenesis process. VEGF-C, a member of the VEGF family, contitutes one of the growth factors that plays a role in the proliferation of endothelial cells, and the increase of VEGF-C expression would raise the VEGF-C level. Thus, it was of interest to study whether there was an increase of VEGF-C levels in patients with early stage cervical cancer that had metastasized into lymph node. This study aimed to prove and identify the sensitivity and specificity of the examination of VEGF-C level in detecting metastasis of cervical carcinoma into pelvic lymph node. 


\section{METHODS}

Design of this study was a case-control study in which the cases were cervical cancers with metastasis into pelvic lymph node, and controls who were cervical cancer patients without metastasis into pelvic lymph node. Samples of the study were patients with stage IB-IIA cervical cancer undergoing radical hysterectomy. Independent variables analyzed were, among others, VEGF level, primary lesion size, histological type, differentiation degree, and lymph vascular space invasion. On the other hand, dependent variable analyzed was, among others, metastasis into pelvic lymph node. VEGF-C level was measured by means of ELISA examination with value unit of $\mathrm{pg} / \mathrm{ml}$.

\section{RESULTS}

As many as 47 cases met the criteria of the study. On normality test, it could be concluded that data of VEGF-C levels with Chi2 test and Saphiro-Wilk were distributed in accordance with normal data distribution $(\mathrm{p}=0.14244)$.

\section{Bivariate analysis}

Table 1. Correlation between variables of primary lesion size, histological type, degree of cell differentiation, and lymph vascular space invasion with metastasis into pelvic lymph node.

\begin{tabular}{|c|c|c|c|c|c|}
\hline & \multicolumn{2}{|c|}{ Lymph node metastasis } & \multirow[t]{2}{*}{ OR } & \multirow[t]{2}{*}{$(95 \% \mathrm{CI})$} & \multirow[t]{2}{*}{$\mathrm{p}$ value } \\
\hline & Negative & Positive & & & \\
\hline \multicolumn{6}{|l|}{ Primary lesion size } \\
\hline$-\quad \leq 40 \mathrm{~mm}$ & 30 & 7 & 1 & & \\
\hline - $\quad>40 \mathrm{~mm}$ & 3 & 7 & 10 & $2.05 ; 48.69$ & 0.004 \\
\hline \multicolumn{6}{|l|}{ Histological type } \\
\hline - Squamous cell carcinoma & 20 & 6 & 1 & & \\
\hline - Adenocarcinoma & 9 & 4 & 1,48 & 0,$33 ; 6,57$ & 0.605 \\
\hline - $\quad$ Adenosquamous & 4 & 3 & 2,50 & $0.43 ; 14.43$ & 0.306 \\
\hline - Other & 0 & 1 & & & \\
\hline \multicolumn{6}{|l|}{ Cell differentiation degree } \\
\hline - Good & 10 & 0 & & & \\
\hline - Moderate & 13 & 7 & & & \\
\hline - $\quad$ Poor & 10 & 7 & 2,76 & $1.03 ; 7.42$ & 0.043 \\
\hline \multicolumn{6}{|l|}{ Lymph vascular space invasion } \\
\hline - Negative & 20 & 1 & 1 & & \\
\hline - $\quad$ Positive & 13 & 13 & 20 & $2.32 ; 171.77$ & 0.006 \\
\hline
\end{tabular}




\section{VEGF-C Characteristics}

Based on the calculation of sensitivity and specificity and ROC analysis for VEGF-C, we found a cut point of $10,066.90 \mathrm{pg} / \mathrm{ml}$. Patients with serum VEGF-C levels $>10,066.90 \mathrm{pg} / \mathrm{ml}$ were at risk for metastasis into pelvic lymph node (odds ratio, OR 80) as high as that of serum VEGF-C level $\leq 10,066.90$ with CI of 7.99;800.71 and $p$ value $=0.000$.

As many as 4 variables which had a $p$ value $<0.05$ in bivariate analysis were included in multivariate analysis. We performed analysis with stepwise backward elimination method, and found 3 variables, i.e., VEGF-C level (95\% CI $0.00027-0.0016$ with $p$ value $=0.006)$, primary lesion size $(95 \%$ CI $0.87 ; 4.06$ with $p$ value $=0.206)$, and lymph vascular space invasion (95\% CI -0.81-7.94 with $p$ value $p=0.111$ ). Variables of primary lesion size and lymph vascular space invasion had significant $p$ values if VEGF were excluded from the model. It could be concluded that these data showed that the variable of VEGF-C constituted the most determining variable in the metastasis into the pelvic lymph node.

\section{Sensitivity, specificity and probability of VEGF levels in detecting lymph node metastasis}

Based on cut-off point of VEGF-C level, i.e., 10,066.90 $\mathrm{pg} / \mathrm{ml}, 11 / 47$ patients with or $23.41 \%$ had the level above that value, and $10 / 11$ of that patient group or $90.91 \%$ were found to have metastasis into the pelvic lymph node.

The sensitivity of the examination of VEGF-C levels in relation to the risks for lymph node metastasis in this study was $71.43 \%$, with specificity of $96.97 \%$, positive predictive value (PPV) of $90.91 \%$, and negative predictive value of $88.89 \%$.

Table 2. Odds ratio, $\mathrm{CI}$ and $\mathrm{p}$ value for the occurrence of metastasis into lymph node according to the characteristics of VEGF-C serum level.

\begin{tabular}{|c|c|c|c|c|c|}
\hline & \multicolumn{2}{|c|}{ Lymph node metastasis } & \multirow{2}{*}{$\overline{\mathrm{OR}}$} & \multirow[t]{2}{*}{$(95 \% \mathrm{CI})$} & \multirow[t]{2}{*}{$p$ value } \\
\hline & Negative & Positive & & & \\
\hline VEGF-C level & & & & & \\
\hline$-\quad \leq 10,066.90$ & 32 & 4 & 1 & & \\
\hline$-\quad>10,066.90$ & 1 & 10 & 80 & $7.99 ; 800.71$ & 0.000 \\
\hline
\end{tabular}

Table 3. Correlation between VEGF-C level and stage of the disease and primary lesion size

\begin{tabular}{cccccc}
\hline & \multicolumn{2}{c}{ VEGF-C Level } & OR & $(95 \% \mathrm{CI})$ & p value \\
\cline { 2 - 3 } & $\begin{array}{c}\text { Negative } \\
<\text { cut off }\end{array}$ & $\begin{array}{c}\text { Positive } \\
\geq \text { cut off }\end{array}$ & & & \\
\hline $\begin{array}{c}\text { Primary lesion tumor } \\
-\quad \leq 40 \mathrm{~mm}\end{array}$ & 31 & 6 & & 1 & \\
$-\quad>40 \mathrm{~mm}$ & 5 & 5 & 5.16 & $1.13 ; 23.54$ & 0.034 \\
\hline
\end{tabular}

\section{Multivariate analysis}

Table 4. Variables included in multivariate analysis

\begin{tabular}{lccc}
\hline \multicolumn{1}{c}{ Variables } & OR & $(95 \%$ CI $)$ & $\mathrm{p}$ value \\
\hline VEGF-C Level $\geq 10,066.90$ & 80 & $7.99 ; 800.71$ & 0.000 \\
Primary lesion size $\geq 40 \mathrm{~mm}$ & 10 & $2.05 ; 48.69$ & 0.004 \\
Positive lymph vascular space involvement & 20 & $2.32 ; 171.77$ & 0.006 \\
Differentiation & 2.76 & $1.03 ; 7.42$ & 0.043 \\
\hline
\end{tabular}


Table 5. Distribution based on VEGF-C levels and lymph node metastasis

\begin{tabular}{|c|c|c|c|c|c|}
\hline \multirow{3}{*}{$\begin{array}{l}\text { VEGF-C Level } \\
\text { (cut off point) }\end{array}$} & \multicolumn{4}{|c|}{ Pelvic lymph node metastasis } & \multirow{3}{*}{$\begin{array}{c}\text { Total } \\
\text { N }(\%)\end{array}$} \\
\hline & \multicolumn{2}{|c|}{ Negative } & \multicolumn{2}{|c|}{ Positive } & \\
\hline & $\mathrm{n}$ & $\%$ & $\mathrm{n}$ & $\%$ & \\
\hline$\leq 10,066.90$ & 32 & 96.97 & 4 & 28.57 & $36(76.59 \%)$ \\
\hline$>10,066.90$ & 1 & 3.03 & 10 & 71.43 & $11(23.41 \%)$ \\
\hline Total & \multicolumn{2}{|c|}{$33(70.21 \%)$} & \multicolumn{2}{|c|}{$14(29.79 \%)$} & $47(100 \%)$ \\
\hline
\end{tabular}

\section{DISCUSSION}

Therapy of early stage cervical cancer is surgery or radiation therapy, and the outcome of surgical therapy is not different from that of radiation therapy. Several advantages of surgical therapy include milder side effects of therapy with shorter period of recovery than that of radiation therapy. Survival of surgery for early stage cervical cancer is heavily affected by several prognosis factors. A number of prognostic factors for surgery of early stage cervical cancer include, among others, clinicopathologic factors and metastasis factors into lymph node. Clinicopathologic factors, such as primary lesion size, histological type, grade of tumor differentiation, could be identified prior to surgery. On the other hand, metastasis into lymph node could be identified after surgery. Five-year survival of cervical cancer patients undergoing surgery with metastasis into pelvic lymph node stood approximately at $85 \%$, and this survival rate would decrease to $50 \%$ if tumor metastasis into pelvic lymph node was found on surgery. ${ }^{2,3}$ Five-year survival could increase to $55 \%$ if patients received post-surgical adjuvant therapy of radiation when the tumor had metastasized into pelvic lymph node., ${ }^{4,5}$

Detection of tumor metastasis into lymph node is relatively difficult to do and expensive (CT scan or MRI examination). Therefore, it is necessary to have an examination method capable of detecting metastasis of cervical cancer into pelvic lymph node which is feasible to perform and affordable. VEGF is a growth factor playing a role in the angiogenesis process which constitutes part of the metastasis process. The increase of VEGF levels would stimulate the activity of angiogenesis. ${ }^{6}$

In our study, there were 4 variables which in bivariate analysis affected the incidence of metastasis of stage IB-IIA cervical cancer into pelvic lymph node, i.e. variables of VEGF-C, primary lesion size, lymph vascular space invasion, and cell differentiation degree. Primary lesion $>4 \mathrm{~cm}$ constituted one of the prognosis factors of tumor metastasis into pelvic lymph node.
The incidence of cervical cancer metastasis into pelvic lymph node in stage IB-IIA cervical cancers with primary lesion size $>4 \mathrm{~cm}$ was approximately $35.2 \%$. On the other hand, metastasis incidence in primary lesion $<4 \mathrm{~cm}$ was approximately $21.1 \%{ }^{1}{ }^{1}$ Lymph vascular space invasion was a tumor embolus in lymph vessels or blood vessels which indicated the presence of tumor invasion into lymph vessels or blood vessels. Tumor emboli in lymph vessels or blood vessels would increase the risk of tumor metastasis. ${ }^{7}$ Cell differentiation degree showed some cell changes, and in good differentiation degree no cell changes had been found to deviate from the mother cells. By contrast, tumors with poor differentiation degree showed enormous cell changes from the mother cells. Such changes showed tumor aggressiveness, tumors with poor differentiation degree were generally aggressive with unfavorable radiation therapy or chemotherapy. Compared with tumors of moderate or good differentiation, tumors with poor differentiation degree were more unfavorable in terms of survival.

VEGF is one of the proteins playing a role in the process of angiogenesis and lymph genesis. The process of angiogenesis and lymph genesis contitutes an important part in the incidence of metastasis and survival of tumor cells, such that VEGF expression affects the incidence of angiogenesis and lymph genesis. Lymph genesis represents a series of metastatic processes of lymphogene into lymph node. ${ }^{8}$ The enhanced expression of VEGF would increase the incidence of angiogenesis and lymph genesis as well as VEGF level in the blood. The enhanced expression of VEGF also serves as a sign for the increased incidence of either hematogene or lymphogene metastases. Thus, it was of interest to study the correlation between VEGF levels and the incidence of metastasis into pelvic lymph node. ${ }^{9,10,11}$

On multivariate analysis, VEGF-C level contitutes a variable that has a correlation with the incidence of metastasis into pelvic lymph node. Therefore, VEGF-C represents a stronger predictive variable of metastasis into pelvic lymph node than other variables and a VEGF 
level $>10,066.90 \mathrm{pg} / \mathrm{ml}$ indicates metastasis of cervical cancer into pelvic lymph node. By using a cut off point of $10,066.90 \mathrm{pg} / \mathrm{ml}$ the sensitivity of the VEGF-C level in relation to the risk for the incidence of lymph node metastasis in this study is $71.43 \%$, with specificity of $96.97 \%$, a positive predictive value (PPV) of $90.91 \%$, and a negative predictive value of $88.89 \%$. The results of this study show that VEGF-C level can be used to predict the presence or absence of cervical cancer metastasis into pelvic lymph node. Examination of VEGF-C levels can be performed as screening criteria for the cases appropriate for immediate surgery.

In conclusion, VEGF-C level $>10,066.90 \mathrm{pg} / \mathrm{ml}$ indicates a risk for developing metastasis of cervical cancer into pelvic lymph node and this value can be used to predict such metastasis with a sensitivity of $71.43 \%$, specificity of $96.9 \%$, a positive predictive value of $90.91 \%$, and negative predictive value of $88.89 \%$.

\section{REFERENCES}

1. DiSaia PJ, Creasman WT. Clinical Gynecologic Oncology. Sixth edition. Mosby Inc, Missouri.2002;53-112.

2. Sevin BU, Nadji M, Lampe BY, Hilsenbek S, Koechli OR, Averette HE. Prognostic factors of early stage cervical cancer treated by radical hysterectomy. Cancer. 1995;76:1978-86.

3. Pieterse QD, Trimbos JBMZ, Dijkman A, Creutzberg CL, Gaarentstroom KN, Peters AAW, Kenter GG. Postoperative radiation therapy improves prognosis in patients with ad- verse risk factors in localized, early-stage cervical cancer : a retrospective comparative study. Int J Gynecol Cancer 2006;16:1112-8.

4. Micha JP, Goldstein BH, Rettenmaier MA, Brown JV, John CR, Markman M. Surgery alone or surgery with a combination radiation or chemoradiation of management of patients with bulky-stage IB2 cervical carcinoma. Int J Gynecol Cancer. 2006;16:1147-51.

5. Zola P, Landoni F, Torri W, Buda A, Mazzola S. Randomised controlled trial of adjuvant treatment in early cervical cancer. 13th International Meeting of ESGO, Brussel, 2003 April 6-10.

6. Kodama J, Seki N, Tokumo K, Hongo A, Miyagi Y, Yoshinouchi $\mathrm{M}$, et al. Vascular endothelial growth factor is implicated in early invasion in cervical cancer. Euro $\mathrm{J}$ of Cancer.1999;35(3):485-9.

7. Lee KBM, Lee JM, Park CJ, Lee KB, Cho HY, Ha SY. Lymph node metastasis and lymph vascular space invasion in microinvasive squamous cell carcinoma of the uterine cervix. Int J Gyn Cancer.2006;16(3):1184-7.

8. Hashimoto I, Kodama J, Seki N, Hongo A, Yoshinouchi M, Okuda $\mathrm{H}$, et al. Vascular endothelial growth factor-C expression and its relationship to pelvic lymph node status in invasive cervical cancer. British J of Cancer. 2001;85:93-7.

9. Detmar M, Hirakawa S. The formation of lymphatic vessel and its importance in the setting of malignancy. Th J of Exp Med.2002;196(6):713-8.

10. Pinedo HM, Slamon DJ. Translational Research: The role of VEGF in tumor angiogenesis. The Oncologist.2000;5(1):1-2.

11. Stacker SA, Baldwin ME, Achen MG. The role of tumor lymphangiogenesis in metastatic spread. The Faseb J. 2002;16 July:922-34. 